\title{
Book Roviews
}

\section{うまい英語で医学論文を書くコツ}

著者 : 植村研一

出版者 : 医学書院

価格 : 2,900円
出版年 : 1991

ページ数 : 226p.

ISBN : 4-260-13630-5
正しい英語といい, 使える英語, 生きた英語, など英語を形容するコトバが多いということには， 現今の英語状況があらわれている。また，英語に 寄せるさまざまな思いがあらわれている。

こんどあたらしく「気持ちの良い英語」がつけく わわった。ここで「気持ちの良い」といわれている のは, 固い英語, ぎくしゃくとした英語の先に，ま た文法的にはまちがっていない, 理解はできるが, など留保のつく英語の先にイメージされている。

著者は, 浜松医大の脳神経外科教授。留学をふ くめて豊富な英語経験をもつ。現在浜松医大 3 ・ 4 年生を対象に「医学英語セミナー」を担当して いる。そこで学生にかかせた英作文の添削例, と 「神経外科」誌で英語論文の英文添削を行ってき た，そこでの添削例のなかから日本人の英語の uncomfortableness を代表する例を整理して, 丁寧な解説をくわえたものがこの本の中心になっ ている。

著者は, 米英人（ことにアメリカ人）は論点を 簡潔かつ明快に直接的に表現するのを comfortable と感じている, という。たとえば JAMA の 編集長をながく勤めた King は, 簡潔さ・明快 さを原稿に求め, とくに短くするだけで, よい英 語になるといっている，という。

しかし，日本人のばあいこれだけでは不十分と いう。文化的, 言語的背景の違いから, いわゆる 和文英訳では気持ちの良い表現にはならない。

「文法的には正しい英語」と米英人の好む「気
持ちの良い英語」との違いについて，一定の法則 がある。この法則にもとづいた訓練を行うことが 必要というのが著者のかんがえ。題名にコッとう たれたのも，それらがいくつかに整理されるとい うことであある。

タイトルページの at head of title の位置に A guide to comfortable English とあるが, こ こから医学論文に必要な英語は comfortable な 英語のことだということがわかる。題名中の「う まい英語」は comfortable Englishのことなのだ。 医学論文に求められる「気持ちの良い英語」に は「気持ちの良い日本語」と共通点がある, とい う。いずれも相手が理解しやすいように簡潔にま とめあげられている。

科学論文のライティングガイドに必要な要素と

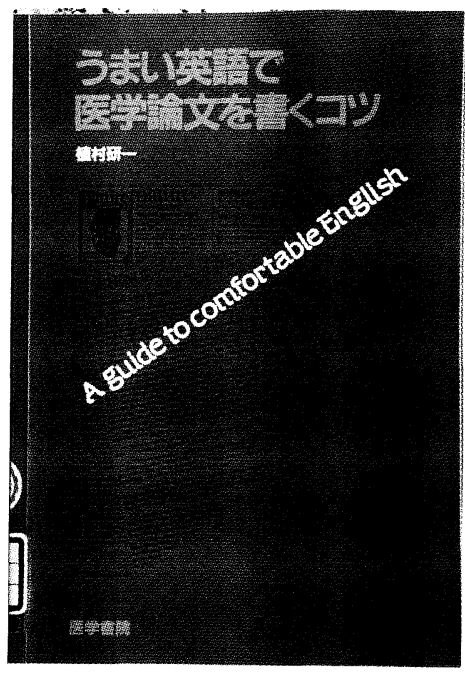




\section{Book Reviews}

$し て$ Elements of the scientific papers の著者 Kats は発表形式（フォーマット）, 言語, 発表 手続きをあげているが，この意味では言語につい てほとんよ゙のページをさいている。

医学英語論文で多用されがちな受動態について も，「医学英語論文で受動態を使わなければなら ない唯一最大の理由は，著者自身が能動態の主体 になることが多いから」など著者の説明はどのぺー
ジも明快だ。また，英語論文を読む際にも，「自 分だったらここにこの冠詞，前置詞をつかっただ ろうか」を自問することをすすめているなど, 実 際的なアドバイスに満ちている。

著者は若い医学徒向けにかいたとしているが， 英語状況から逃れられないわたしたち医学図書館 員にも参考になる本と思う。

（埼玉医科大学附属図書館 小野沢繁雄）

\section{本はいつごろから作られたか : 大発見 4}

\author{
著者 : Daniel J. Boorstin 著 \\ 鈴木主税, 野中邦子訳 \\ 出版者 : 集英社 \\ 出版年 : 1991
}

ISBN : 4-08-760206-0

ページ数 : $284 \mathrm{p}$.

価格 : 550円
原著の “The Discoverers”『大発見』は，人 間の生活に変化をむたらした歷史上の大きな発明・ 発見をとりあげ，「第 1 章天上の帝国」から「第 15章現在を概観する」までの15章で構成されてい る。このうち本書は第 4 分冊にあたるが，内容は 「第12章すべての生物を分類する」と「第13章知 識の共同体を広げる」である。ここでは第13章に ついて紹介する。

印刷技術が発明される以前数千年にわたって知 識の保存庫は記憶術であったが，印刷術の発明と その利用が社会をどのように変え，方向付けていっ たかを，主としてヨーロッパの言語の成熟に焦点 を当てて述べている。なかでも「地域語の共同体」 の章では, 活字本の普及がヨーロッパの学問の言 語をラテン語から各地方の日常語に变え, さらに 各地方の標準語となる言語を形成していく過程が 述べられている。印刷術という一つの技術が原動 カとなって，15世紀から16世紀のヨーロッパ各国
に, 現在に至る言語を形成させていったというこ とは, 一つの感動であると言える。ウィリアム・ カクストンがフランス語から翻訳した『哲学者言 行録』はイングランドで印刷された本としては最 あ古い日付をあつものであるが，カクストンはま ず “英語」に翻訳する以前に，まさしく「英語」

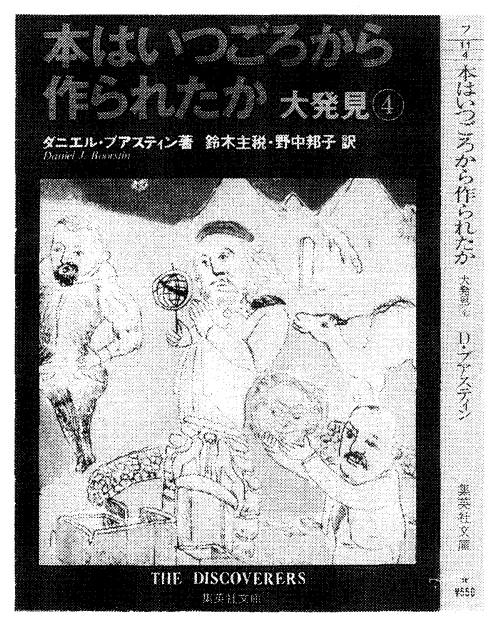




\section{Book Reviews}

とは何かを決定しなければならなかった”と述 べている。このようにラテン語で記述されていた 学問や知識が, 印刷術の発明によって, 各国語で 記述されていく過程を示している。

さらに「世界文学をめざして」の章では，16世 紀から19世紀の各国の辞書の編纂が標準語を形成 し,国語の正書法を定めていった過程が述べられて いる。

『本はいつごろから作られたか』という本書の 書名からは多少離れるが，印刷術すなわち今日的 な意味での印刷された本が，知識の共同体を拡げ るために果たしてきた役割が，各国語の形成とい う過程をへてきている事を示している点で, 本書 は我々に新しい視点を与えてくれている。文字や
言葉の長い歴史の中で印刷術が生まれ，その器の 中で現代に至る言語が形成され育てられたことを， 思い出させ再考させるものとして，本書はわかり やすく書かれておりすぐれた著作である。また文 庫本という形態む我々にはなじみやすい。

関連書として，印刷術の歴史や現代日本語とワー プロについて述べている『知的生産の文化史 ワー プロがあたらす世界』(阿辻哲次著, 丸善ライブ ラリー，1991）や，日本語文化とワープロについ て述べている『ワープロが社会を变える』（田中 良太著, 中公新書, 1991）などが最近手軽な本と して出版されている。

（浜松医科大学附属図書館 江口 愛子）

\section{カッコウはコンピュータに卵を産む（上・下）}

著者：Clifford Stoll

出版者 : 草思社

ページ数 : 595p.（上・下）

ISBN : 4-7942-0430-2（上), 4-7942-0431-0（下）
訳者 : 池央 耿

出版年 : 1991

価格 : 各1,900円

映画『ウォー・ゲーム』のようなことが現実に 起こる可能性はあるだろうか？ 10代のハッカー が，ペンタゴンのコンピュータに侵入して戦争を ひき起こしてしまうというようなことが実際にあ り得るだろうか？ 防禦が厳重である筈の軍事施 設や研究所にハッカーが入り込んでいる事実は, よく新聞等で報道されているが，本書は，ひょん なことからハッカーを発見し，10カ月にわたって 追跡してっきとめていった，アメリカの若き天文 学者の自らの筆になるドキュメントである。

そもそもの発端は, 天文学研究者クリフが，ロー レンス・バークレイ研究所のコンピュータ・シス

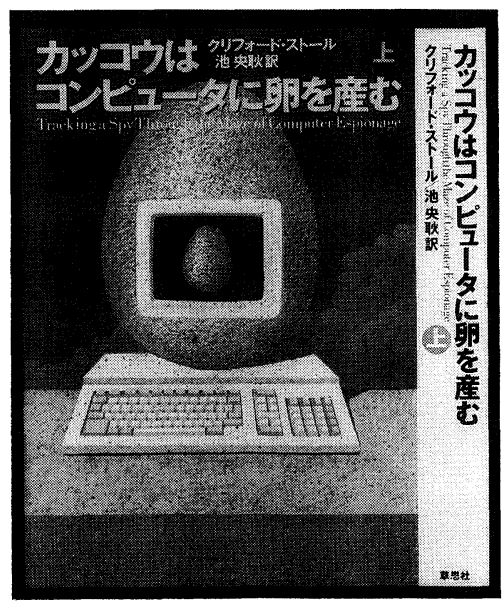




\section{Book Reviews}

テムの管理をまかされ，コンピュータの使用料が 75セント合わないことに気づいたことに始まる。 何者かが，ネットワークに侵入し，システムの穴 とも言える欠陥をついて, 様々な特権を有するスー パー・ユーザーになりすまして, 国防上枢要な軍 事施設のコンピュータに次々と侵入してゆくのだっ た。

カッコウは, 他の鳥の巣に卵を産んで, ひなを かえすことを他の鳥に托すという。この謎のハッ カーも, カッコウの如く, 卵にあたるプログラム を侵入した先のコンピュータに産みこみ, システ ムが卵を抱いて，ひながかえるのをじっと待って いる。やがてかえったひなには, システム上の様々 な特権（餌）が与えられるのであった。ハッカー の手口は実に巧妙といえる。

こうして, バークレイ研究所のコンピュータを 足場に, ハッカーは国防総省のネットワークをく ぐって, 各地の軍事施設や基地のコンピュータに 侵入し, 軍関係のデータベースを読みあさって, C I Aの情報にまで手をのばしてゆくのだった。
クリフは, ハッカーの動きを逐次監視する方法 を独力で編み出し, 官憲の協力が得られない中で 逆探知を進めてゆくその過程は, ハイテク時代に 生きる, 新007さながらの活躍ぶりである。

現代社会において，意識する，しないを問わず, 私達は,コンピュータに依存する生活を送ってい るといえるだろう。また, 情報化社会にあっては, コンピュータをいかに有効に活用し, 使いこなし てゆくかが重要課題ともいえる。先端分野であれ ばある程, 高密度にはりめぐらされたコンピュー タネットワークを駆使し, 最新の情報を獲得し, また膨大なデータの蓄積の中から必要なあのをと り出すことが日常頻繁，かつ不可欠なものとなっ ている。

そんな状況の中で, 本書によって描かれた事実 のもつ迫力は, まさに, 新しい時代にふさわしい 倫理感, 換言すれば“電子モラル”なるものの必 要を, 読後痛切に感じさせられるのである。

（慶應義塾大学医学情報センター 鈴木 雅晴）

\section{図書館員のための英会話ハンドブック：海外旅行編}

著者 : 京藤松子ほか

出版者 : 日本図書館協会

出版年 : 1991.10
ページ数 : $185 \mathrm{p}$.

価格 : 定価1,500円（本体価格1,456円）

ISBN : 4-8204-9110-5
今, 海外旅行は国内を旅行するのとほとんど変 わらないくらい身近なものになっている。また， 最近では国際的な学会や海外研修に出かける機会 む増えている。図書館員のなかには，このような 機会に現地の図書館を視察しようと考える人も少 なくはないであろう。このハンドブックはそのよ うな人々にとっての“力強い友”である。
ポケットサイズなのでどこにであ手軽に持ち歩 けるし，ほとんどの部分が見開きで完結している ので大変使いやすい。内容についても, 企画段階 からアポイントメントをとる, 現地での前準備, 本番, 帰国後の礼状といった海外訪問の一連の流 れが全て網羅されている。

そのうち, “現地での前準備”から“図書館に 


\section{Book Reviews}

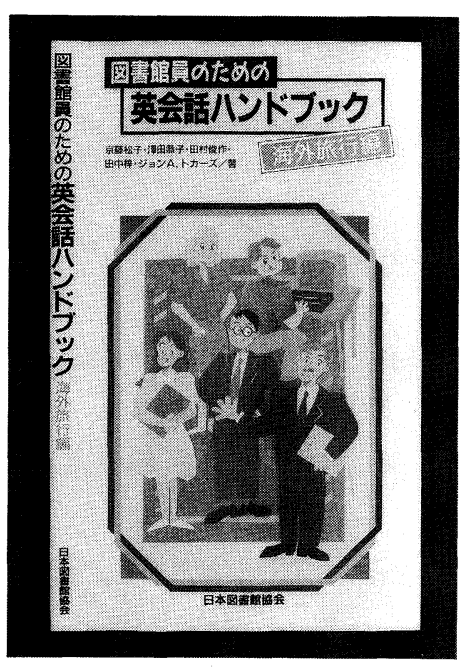

到着するまで”と, “図書館を去る時” の部分は, 訪問者と現地の人との対話が多数例示されている。 実に様々な場面が想定されており（例えば “間違 い電話を謝る場面”や“行き先を確かめてバスに 乗る場面”等々), その場面ごとの対話がユニーク でおむしろい。また，ところどころに，“電話を かけるときの心得”, “チップの量”, “握手のし かた”, “土産の渡しかた”等, 旅行先での細か いマナーに関するアドバイスが挿入されている。

このハンドブックのメインである“訪問先の図 書館での見学”の章は, 全て左頁が日本語・右頁 は英語という形で統一されている。そして章全体
が見学の流れにそって9つの “SCENE”（概要, 閲覧・貸出サービス, 参考業務, 効果的サービス, 資料, 整理業務, 電算化, 職員等) に区切られて おり，それぞれの“SCENE” の中に適切な質問 事項が満載されている。これらにそって質問をし ていけば, 訪問先の図書館の全体像を浮き彫りに することができるであろう。さらに余白には細か い補足説明と, Vocabulary の補充がつけられて いる。つまり, 海外訪問の際にあらがじめこの章 を読み，どの見学事項（“SCENE”）にポイン トをおくかを決めて，その中から質問事項をピッ クアップしておけば，無駄なくかつ有意義な視察 ができるのである。欲を言えば，それぞれの “SCENE” の終わりに，その部分に関連する単 語の一覧がついていると一層便利だと思う。

最後に,このハンドブックは, 海外に行く図書 館員を対象として編集されたものであるが，海外 に足を運ばない図書館員にとっても便利であると 私は思う。最近, 日本の図書館を視察に来る海外 の図書館員も増えている。このハンドブックがあ れば，相手の質問事項を知る手がかりとなり，い かなる資料をそろえ，どのような回答を用意すれ ばよいかといった事前準備に役立つであろう。

（東京大学医学図書館 小川喜美江） 


\title{
Book Reviews
}

\section{死ぬ瞬間 : 死にゆく人々との対話}

\author{
著者 : Elisabeth Kübler-Ross \\ 訳者 : 川口正吉 \\ 出版者 : 読売新聞 \\ 出版年 : 1985
}

ページ数 : $315 \mathrm{p}$.

上記の図書は,「続死ぬ瞬間」「新死ぬ瞬間」 「死ぬ瞬間の対話」「死ぬ瞬間の子供たち」(『死ぬ 瞬間』の誕生）と続く, 一連のシリーズの最初の 出版物である。

今や, 医学の臨床現場では, 患者の Quality of life を考えた末期医療や尊厳死の問題がクロー ズアップされてきている。

今回紹介する本は，死の床にある患者や家族達 を勇気づけるための, 先駆的著書であり, また, 末期患者の真のニードや心理過程を理解する上で 貴重な本である。

昔は, 病院で死ぬよりむ家で死方が多かった ようである。しかし現在では，末期患者は病院へ 送り込まれ，病院という組織による患者管理や， 治療中心の医療が行われている。ロス博士は, 病 院という管理下で末期を過ごす患者が，本当に必 要とするものは何であるのか，また死にゆくとは どのようなことなのかということを，患者自身か ら学ぼうと取り組んだのである。

末期患者に，「死ぬとはどういうむのか？どん な恐れや要求を持つのか? 私達が役に立つこと, また害になるのはどんなことか？」と尋ねること から始まったこの試みは, 当初, 医療スタッフの 間に辛辣な批判を招き, 医師達の困惑, 不快, 憮 然とした敵意に遭遇した。

しかし，それに反してインタビューを受けた患 者達は, 死に直面した絶望感と常に放棄され, 一
人きりでいる孤独感から開放され, 今まで口に出 さなかったコミュニケーションの意欲を明らかに 示したのである。臨死患者達は，ほとんど例外な く, 感謝の念と大きな安堵とを感じたようである。 本文を読むと, 病人の目線と同じ位置での患者自 身の告白記録であり，ひたすら謙虚に聞くことに 徹したものであることがわかる。

この試みは, 次第に, 末期患者に接する時間や 機会の多い看護婦さんや，あるいは，末期患者の 心理を学ぶ必要性を感じ始めた医師等によって支 持されていくのである。

全12章から成るこの本の序文で，著者は，「こ の本は死にかかった患者の管理方法を教える教科 書であなく，死にゆく人の心理の完全分析を目指 したものであない。ただ患者を, 一人の人間とし

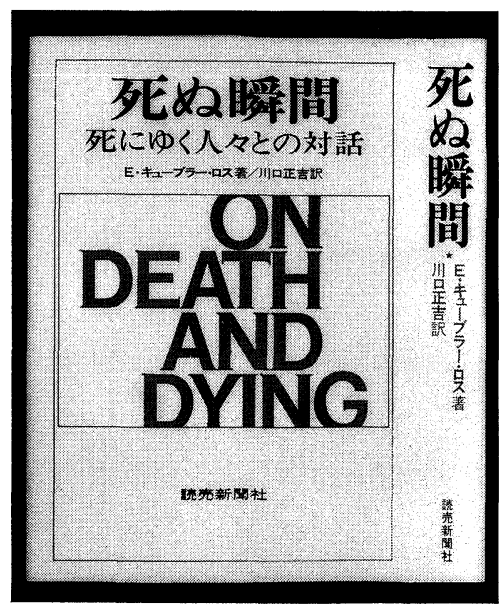




\section{Book Reviews}

て見直す，この角度から焦点を当て直そうという， 全く新しいチャレンジングな記録にすぎない」と 述べている。

本文の 1 ～章では, 死の恐怖や告知是非の問 題を取り上げ， $3 \sim 7$ 章では，末期患者が，どの ような段階を経て死の瞬間を迎えようとするかを 200余人のインタビューの中から事例をあげて分 析していく。すなわち, 心理過程の第一段階は病 気の否認であり，第二段階の怒り，そして第三段 階は神や人との取り引きを願い，第四段階でそれ

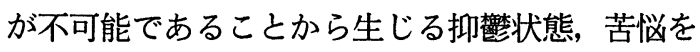
経て, 第五段階の受容と平和の時期を迎える, と いう一連の分析である。

そして第八章以降は, 患者にとっての希望の意 味や, 家族との問題, また末期患者の精神療法な どにふれている。

最後に著者は, 「患者と家族を助け, 不可避の 現実を一緒に受容できるよう仕向けることができ
るなら, 死にゆく人の不必要な懊悩や, 苦痛を避 けることができる。一中略一私達は, 患者にとっ ては死そのものは問題ではなく, 死にゆくことが, それに伴う絶望感と無援感と隔離感ゆえに怖しい のであることを学んできた。一中略一患者は最後 の瞬間まで何らかの形で希望を持ち続けていた」 と結論している。

すなわち患者には, 平安と威厳の内に死権利 があるのだから，医療従事者は，死に至る患者の 心理過程を理解する必要があることを示している。 続巻を含め, 小児をあわせて 1,000 人以上のイ ンタビューに基づいた, 死の心理学に大きい足跡 を残す書物である。

インドの聖人, タゴールの文章を, 各章の扉に 付していることも興味深い。

（昭和大学附属烏山高等看護学校図書室 和田佳代子） 